Discusión

\title{
Trastornos hidroelectrolíticos en el postoperatorio de cirugía ortognática
}

\author{
Hydroelectrolytic disorders following orthognathic surgery
}

Aunque las pérdidas de líquidos que ocurren durante el período pre e intraoperatorio suelen ser corregidas pueden aparecer alteraciones hidroelectrolíticas durante el período postoperatorio asociadas tanto a la intervención quirúrgica como a una enfermedad subyacente del paciente.

Si bien cada paciente debe ser evaluado y tratado de forma individual es conveniente tener presentes unas líneas generales de evaluación del estado de la volemia del paciente al término de la intervención quirúrgica: estado de los líquidos en el preoperatorio, pérdidas asociadas con la intervención, tipo y cantidad de los líquidos aportados durante la misma, valoración clínica del estado habitual de la volemia del paciente y estimación de la cantidad de líquido retenida en los tejidos traumatizados o infectados.

La lectura del artículo "Trastornos hidroelectrolíticos en el postoperatorio de cirugía ortognática", brillantemente presentado de forma clara y precisa, ofrece la posibilidad de realizar una serie de consideraciones.

En primer lugar, y tal y como se hace referencia específicamente en el artículo, las alteraciones de la osmorregulación en el período postoperatorio inmediato no son exclusivas de la cirugía craneofacial y existe un número muy limitado de referencias en la literatura médica; sin embargo, en esta revisión la frecuencia de aparición de estos trastornos es llamativamente elevada. Así, según se refiere, hasta un $55 \%$ de los pacientes ingresados en la Unidad de Reanimación Postoperatoria presentaron una poliuria precoz autolimitada que pudo ser corregida en todos los casos salvo uno con el correcto manejo hidroelectrolítico. Esto nos lleva a realizar una pequeña matización: quizá sería mejor hablar de "desequilibrios hidroelectrolíticos" (desajustes) que de "trastornos hidroelectrolíticos" (inversiones del orden regular).

Por otro lado, para una valoración más precisa de la situación intraoperatoria, que determinará de forma fundamental la evolución del postoperatorio inmediato, habría sido muy interesante hacer constar el tipo de ventilación mecánica utilizada durante la cirugía (de todos es conocida la diferencia en las pérdidas y necesidades en aportes según se utilicen circuitos abiertos, semicerrados o cerrados), el tipo de líquidos aportados (cristaloides y/o coloides), las variaciones de la presión venosa central así como de la temperatura corporal.

Finalmente, creo muy importante insistir en que las alteraciones de la osmorregulación referidas se concretan mayoritariamente en una "poliuria simple autolimitada sin alteraciones hidrolectrolícas", lo cual sumado a los datos recogidos en las tablas adjuntas inclina a pensar en una situación de adaptación fisiológica durante el postoperatorio frente a la agresión quirúrgica que supone este tipo de cirugía, bastante agresiva, y que exige una técnica anestésica acorde y una respuesta del organismo en la misma medida con el objeto de mantener la homeostasis.

No significa con esto que no existan las alteraciones francas de la osmorregulación observadas tras ciertas cirugías, incluida esta cirugía
Although fluid losses occurring during the pre- and intraoperative periods are usually corrected, hydroelectrolytic disorders can appear during the postoperative period that are associated with the surgery as well as with an underlying disease in the patient.

Although every patient should be evaluated and treated individually, it is convenient to keep in mind some general guidelines for evaluating the blood volume level in the patient on concluding the surgery: Preoperative fluid levels, losses associated with the surgery, type of fluids and amount administered during its duration, clinical evaluation of the normal blood volume of the patient and an estimation of the fluids retained in traumatized or infected tissues.

"Hydroelectrolytic disorders during the postoperative period following orthognathic surgery" is brilliantly presented in a clear and precise way, and on reading it one is given the possibility of making a series of reflections.

Firstly, as is specifically stated in article, the alterations in osmoregulation during the postoperative period are not exclusive to craniofacial surgery and there is a very limited number of references in the medical literature. However, in this revision these disorders appear with an unusually high frequency. Thus, according to this, 55\% of the patients admitted into the Postoperative Resuscitation Unit presented early self-limiting polyuria that was corrected in all cases except one with correct hydroelectrolytic management. This leads us to make a small precision: Perhaps it would be better to refer to "hydroelectrolytic imbalances" (disturbances) rather than "hydroelectrolytic disorders" (a reversal of the normal order).

On the other hand, for a more precise evaluation of the intraoperative situation, which is fundamental for determining how the immediate postoperative [period] evolves, it would have been very interesting to have had a record of the type of mechanical ventilation used during the surgery (we are all familiar with the differences in losses and assistance requirements according to whether open, semi-closed or closed systems are used), the type of fluids administered (crystalloids and/or colloids), and the variations in central venous pressure as well in body temperature.

Finally, I believe it is very important to stress that the majority of the disturbances in osmoregulation that are reported [in this article] are largely specific to a "simple selflimiting polyuria with no hydroelectrolytic disorder". This, in conjunction with the data in the accompanying tables, make one more inclined to think that it is the circumstances regarding the physiological adaptation during the postoperative [period] as opposed to the surgical aggression that this type 
en concreto, sino que se debería intentar dilucidar siempre entre estas alteraciones y los "desajustes" fisiológicos secundarios a una importante agresión quirúrgica y anestésica a los que el organismo reacciona en la misma medida. De igual manera creo absolutamente acertada la idea de los autores de realizar una vigilancia constante y un diagnóstico diferencial para la instauración precoz de las medidas correctoras y/o terapéuticas según cada caso.

La base de este artículo es un estudio retrospectivo pero dada su calidad, la importancia del tema que plantea y la serie de cuestiones presentadas que siguen sin tener respuesta sería muy interesante la realización de subsiguientes estudios de carácter prospectivo.

J. L. Marugán Guijo

Facultativo Especialista de Área.

Servicio de Anestesiología-Reanimación. Hospital Clínico San Carlos. Madrid. España of surgery entails, that is quite aggressive and requires an anaesthetic technique to match, and the organism to respond to the same extent in order to maintain homeostasis.

This does not mean that there are no clear alterations in osmoregulation observed following certain surgeries, including this [type of] surgery in particular, rather that one should always try to distinguish between these alterations and physiological "disturbances" that are secondary to a considerable surgical and anesthetic aggression to which the organism reacts in the same proportion. Similarly, I believe to be absolutely correct the view of the authors regarding constant observation and a differential diagnosis in order to adopt corrective and/or therapeutic measures promptly according to each case.

The basis of this article is a retrospective study, but given its standard and the importance of the subject raised together with the series of issues presented that remain unanswered, it would be very interesting for further studies of a prospective nature to be carried out. 